\title{
PEMBUATAN STASIUN KERJA DAN ALAT BANTU UNTUK PROSES PELUBANGAN DAN PENGEPRESAN PADA INDUSTRI RUMAHAN DI DESA KEDUNG DALEM, PASAR KEMIS, TANGERANG
}

\author{
Agustina Christiani $^{1)}$, Ishak $^{2)}$, Priskila Christine Rahayu ${ }^{3)}$, Ario Nugroho Suprapto ${ }^{4)}$, \\ Kevin $^{5}$ \\ 1,2,3,4,5 Program Studi Teknik Industri, Fakultas Sains dan Teknologi, \\ Universitas Pelita Harapan. \\ Jl. MH. Thamrin Boulevard 1100, Lippo Village. \\ e-mail: agustina.christiani@uph.edu
}

\begin{abstract}
A b strak
Di Desa Kedung Dalem, Pasar Kemis, Tangerang, terdapat sebuah industri rumahan yang memproduksi bagian atas sandal wanita. Saat ini proses produksinya masih menggunakan alat yang sangat sederhana, seperti palu, mata pelubang dan mata press. Para pekerja yang semuanya wanita mengeluhkan proses pelubangan dan pengepresan cukup melelahkan karena masih dikerjakan secara manual menggunakan palu. Selain itu pekerjaan dilakukan sambil duduk di lantai karena belum ada meja dan kursi kerja. Oleh karena itu, untuk meningkatkan produktivitas dan memperbaiki postur pekerja, maka pada penelitian ini akan dibuat sebuah stasiun kerja yang terdiri dari meja dan kursi kerja serta alat bantu untuk proses pelubangan dan pengepresan bagian atas sandal wanita. Untuk proses perancangan meja, kursi dan alat bantu digunakan metode quality function deployment $(Q F D)$. Setelah stasiun kerja dan alat bantu dibuat, dilakukan uji coba dan hasil produksi pelubangan dan pengepresan meningkat dari sebelumnya 84 pasang/jam menjadi 128 pasang/jam atau meningkat sebesar 52,4\%. Selain itu, dengan adanya stasiun kerja dan alat bantu, diharapkan dapat mengurangi risiko cedera musculoskeletal pada pekerja, karena skor RULA(Rapid Upper Limb Assessment) dengan menggunakan stasiun kerja tersebut turun dari sebelumnya 7 menjadi 3.
\end{abstract}

Kata kunci: stasiun kerja, alat bantu, produktivitas, QFD, RULA.

\section{PENDAHULUAN}

Beberapa warga perempuan di Desa Kedung Dalem, Pasar Kemis, Tangerang menekuni usaha industri rumahan berupa produksi bagian atas sandal wanita. Proses produksinya terdiri dari pengguntingan bahan sesuai pola, pelubangan, penjahitan, pemasangan asesoris, pengepresan, pengeleman. Proses pengerjaannya masih dilakukan secara manual dengan alat-alat sederhana, seperti gunting, palu, mata pelubang dan mata pres. Selain itu pekerja melakukan pekerjaan tersebut sambil duduk atau berjongkok di lantai karena mereka tidak memiliki meja dan kursi kerja kecuali untuk bagian penjahitan. Berdasarkan wawancara dengan beberapa pekerja, diketahui bahwa mereka dapat mengerjakan ratusan produk per hari. Dengan posisi kerja dan alat sederhana tersebut, mereka menjadi cepat lelah. Contoh posisi pekerja pada saat melubangi bahan dapat dilihat pada gambar 1 .

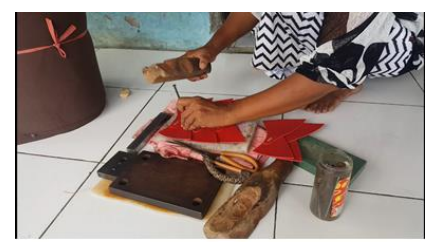

Gambar 1. Proses pelubangan material 
Berdasarkan permasalahan tersebut, maka penelitian ini dilakukan dengan tujuan membuat stasiun kerja berupa meja dan kursi serta alat bantu untuk proses pelubangan dan pengepresan material. Diharapkan dengan adanya stasiun kerja dan alat bantu tersebut, maka produktivitas dan kenyamanan pekerja meningkat.

\section{METODE PENELITIAN}

Metodologi penelitian yang digunakan terdiri dari beberapa tahap sebagai berikut:

\section{Studi pendahuluan}

Pada tahap ini, dilakukan survei ke industri rumahan Desa Kedung Dalem untuk mempelajari sejarah, proses produksi dan hal-hal yang berhubungan dengan industri rumahan tersebut. Studi pendahuluan ini dilakukan dengan metode observasi dan wawancara kepada para pekerja.

\section{Identifikasi masalah}

Berdasarkan studi pendahuluan, dapat diidentifikasi masalah yang ada pada industri rumahan tersebut yaitu proses pelubangan dan pengepresan asesoris masih menggunakan alat tradisional (palu, mata pelubang/pengepres), sehingga proses produksi memakan waktu lama. Selain itu belum ada meja dan kursi kerja, sehingga para pekerja harus mengerjakan proses tersebut sambil duduk di lantai dengan posisi badan membungkuk.

\section{Penentuan tujuan penelitian}

Tahap berikutnya adalah penentuan tujuan penelitian yaitu merancang dan membuat alat bantu untuk meningkatkan produktivitas proses pelubangan dan pengepresan serta merancang dan membuat stasiun kerja (meja dan kursi) untuk mengurangi risiko cedera muskuloskeletal pada pekerja.

\section{Studi pustaka}

Studi pustaka mencakup teori seperti Quality Function Deployment (QFD), House of Quality, dan perancangan alat, antropometri, RULA (Rapid Upper Limb Assessment).

\section{Pengumpulan dan pengolahan data}

Pada tahap ini dilakukan pengambilan data berupa pengukuran kekuatan tarik pekerja dan kekuatan yang diperlukan untuk melubangi kulit sintetis yang akan digunakan untuk menentukan spesifikasi alat bantu. Kekuatan tarik pekerja diambil menggunakan timbangan gantung dan kekuatan melubangi kulit sintetis ditentukan menggunakan mesin uji tarik/tekan. Untuk merancang stasiun kerja, diambil data antropometri para pekerja. Selain itu juga postur pekerja dianalisis menggunakan metode RULA. Data berikutnya yang diambil adalah lama waktu proses pelubangan saat ini serta data waktu proses menggunakan stasiun kerja dan alat bantu yang baru. Ukuran mata pelubangan diukur untuk memastikan bahwa alat bantu sesuai dengan spesifikasi. Selain itu data juga diambil melalui metode wawancara. Dari metode wawancara, data yang diambil adalah keluhan dan saran dari pekerja. Kemudian data-data yang ada diolah untuk membuat house of quality $(H O Q)$. Dari data yang sudah dikumpulkan diatas melalui wawancara dan observasi, kemudian diolah untuk mengetahui kebutuhan pelanggan. Hasil penyebaran kuesioner mengenai tingkat kepentingan kebutuhan konsumen digunakan untuk menentukan tingkat kepentingan ratarata dari setiap kebutuhan. Untuk setiap kebutuhan konsumen ditentukan respon teknisnya. Data antropometri, data kekuatan tarik, dan spesifikasi material digunakan sebagai basis pembuatan spesifikasi target. Dari respon teknis yang didapatkan kemudian ditentukan part kritis. Part kritis ini akan diberikan nilai hubungan dengan respon teknis. Dengan ini akan dibuat matriks baru untuk mengetahui komponen mana yang paling penting. Tahap selanjutnya adalah pembuatan konsep yaitu mengidentifikasi prioritas atribut kebutuhan dari house of quality. Dengan mengetahui prioritas, konsep yang dirancang akan menjadi lebih bagus. Setelah diketahui prioritas atribut kebutuhan, dibuat sebuah morphological chart untuk menggabungkan kombinasi dari ideide konsep yang sudah ada. Dari hal ini akan dibuat beberapa alternatif. Kemudian dilakukan penilaian menggunakan matriks seleksi yang perlu dibuat terlebih dahulu. Setiap kriteria akan diberikan bobot yang sesuai. Dari hal ini akan diketahui alternatif mana yang memiliki nilai tertinggi. Pada tahap ini juga, alternatif yang sudah ada dapat digabungkan atau diperbaiki untuk menghasilkan alternatif terbaik. 


\section{Pembuatan dan uji coba alat bantu dan stasiun kerja}

Pada tahap ini alat bantu dan stasiun kerja dibuat sesuai alternatif konsep rancangan yang dipilih. Setelah itu dilakukan uji coba untuk memastikan apakah alat bantu tersebut sudah berjalan sesuai dengan kebutuhan konsumen. Jika uji coba ini gagal maka spesifikasi alat diubah dan dibuat ulang, jika uji coba ini lolos maka dilanjutkan ke langkah berikutnya.

\section{Perbandingan metode lama dan baru}

Pada tahap ini dilakukan perbandingan produktivitas antara metode lama dan metode baru. Perbandingan dilakukan dengan cara menentukan waktu set up, pelubangan dan pembersihan. Data waktu ini divalidasi dengan uji normalitas, keseragaman dan kecukupan data. Selain itu juga dibandingkan postur tubuh pekerja sebelum dan sesudah perbaikan dengan menggunakan metode RULA.

\section{Penarikan kesimpulan}

Pada tahap ini dibuat kesimpulan dari penelitan yang telah dibuat, kesimpulan ini mencakup seluruh proses dari penelitian hingga hasil dari penelitian ini. Di tahap ini juga dipastikan bahwa penelitian ini sudah memenuhi tujuan yang ingin dicapai.

\section{HASIL DAN PEMBAHASAN}

Identifikasi kondisi pekerja di home industry Desa Kedung Dalem dilakukan dengan cara melakukan pengamatan secara langsung di lapangan. Data hasil pengamatan berupa gambaran postur tubuh pekerja ketika melakukan proses pelubangan dan pengepresan tanpa adanya stasiun kerja dapat dilihat pada gambar 2.

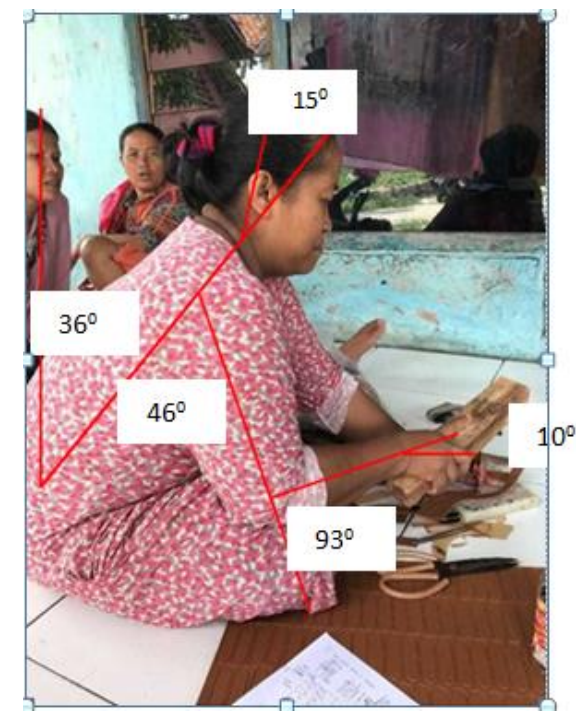

Gambar 2. Postur Kerja (Tampak Samping)

Postur kerja tersebut kemudian dianalisis menggunakan metode RULA dan diperoleh skor akhir $=7$, yang berarti postur kerja tersebut perlu diinvestigasi dan diperbaiki segera (McAtamney dan Corlett, 1993). Penilaian skor RULA secara detil dapat dilihat pada gambar 3. Posisi badan yang membungkuk diakibatkan oleh jarak antara tubuh dan benda kerja yang terlalu jauh karena terhalang oleh kaki pekerja saat duduk bersila di lantai. Perbaikan postur dapat dilakukan dengan cara membuat stasiun kerja yang terdiri dari meja dan kursi. Ketersediaan meja dan kursi kerja akan mendekatkan jarak antara benda kerja dengan tubuh sehingga pekerja dapat duduk dalam posisi tegak. Selain itu proses pelubangan dan pengepresan saat ini masih menggunakan peralatan yang sangat sederhana yaitu palu dan mata pelubang/pengepres, sehingga waktu penyelesaian yang diperlukan lama. Oleh karena itu untuk memudahkan pekerja dalam melubangi material serta mengepres asesoris, maka akan dirancang dan dibuat alat bantu.

Untuk merancang stasiun kerja dan alat bantu perlu diketahui kebutuhan konsumen (dalam hal ini adalah pekerja). Berdasarkan hasil wawancara dengan para pekerja didapatkan pernyataan konsumen seperti dapat dilihat pada tabel 1 . 
Tabel 1. Pernyataan konsumen terhadap alat bantu dan stasiun kerja yang diinginkan

\begin{tabular}{|l|l|}
\hline No & Customer's Statements alat bantu \\
\hline 1 & Alat bantu praktis \\
\hline 2 & Alat bantu tidak melelahkan \\
\hline 3 & Alat bantu mudah untuk dipindahkan \\
\hline 4 & $\begin{array}{l}\text { Alat bantu dapat membuat lubang dengan } \\
\text { bermacam ukuran }\end{array}$ \\
\hline 5 & Alat bantu dapat melubang dan mengepres \\
\hline 6 & Alat bantu tidak menghasilkan cacat \\
\hline 7 & Tampilan yang menarik \\
\hline
\end{tabular}

\begin{tabular}{|l|l|}
\hline No & Customer's Statements stasiun kerja \\
\hline 1 & Meja yang tidak makan tempat \\
\hline 2 & Meja dan kursi yang dapat dipindah-pindah \\
\hline 3 & Meja berguna untuk menyimpan alat dan bahan \\
\hline 4 & Kursi memiliki bantalan duduk \\
\hline 5 & Meja dan kursi mendukung posisi duduk \\
\hline 6 & Meja dan kursi yang tidak cepat rusak \\
\hline
\end{tabular}

\section{RULA Employee Assessment Worksheet}

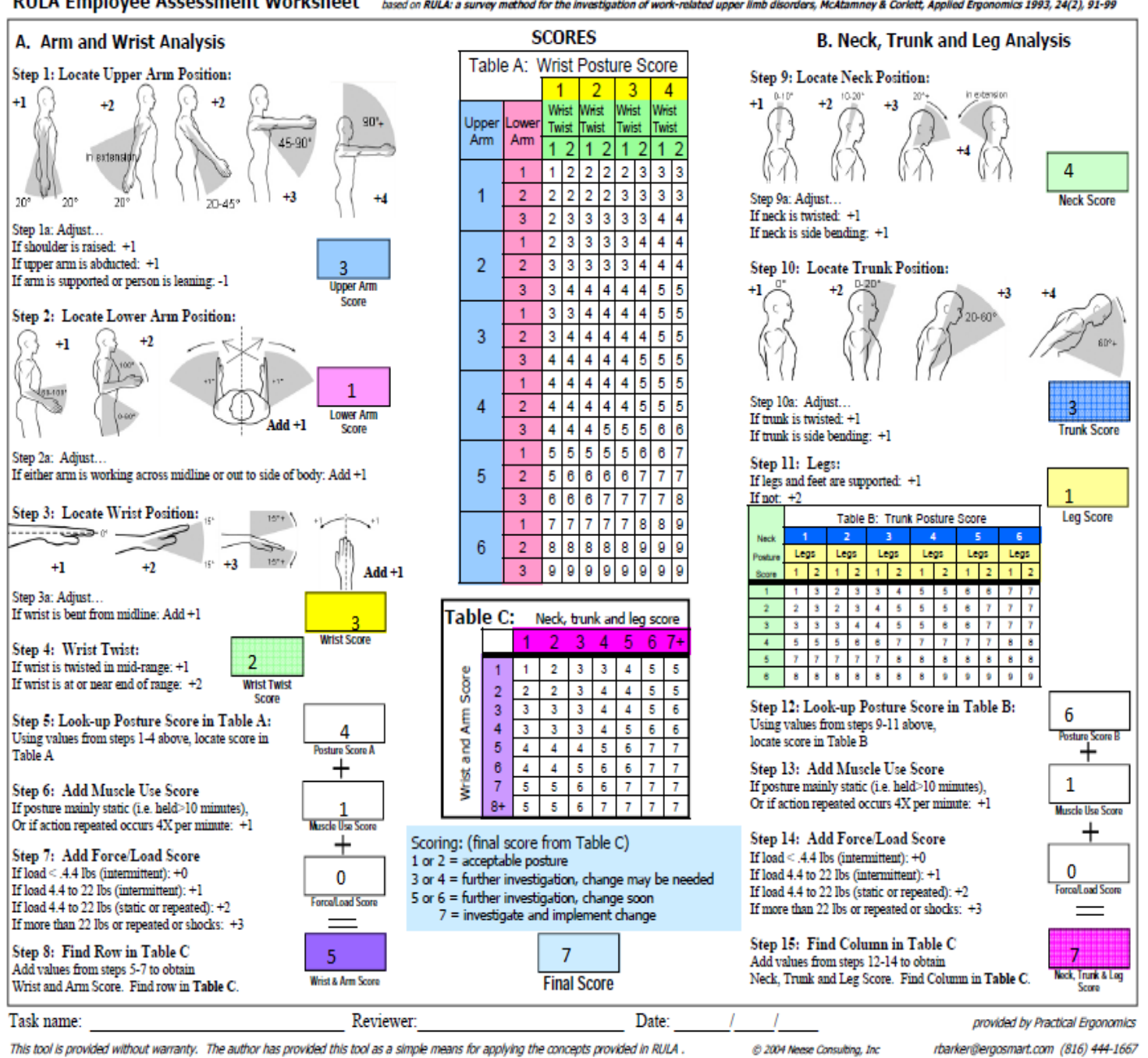

Gambar 3. Skor RULA untuk postur kerja sebelum perbaikan

Berdasarkan data pernyataan konsumen pada Tabel 1, disusun kebutuhan konsumen. Kemudian ditentukan tingkat kepentingan untuk setiap atribut kebutuhan konsumen. Metode yang digunakan untuk mengetahui tingkat kepentingan dari masing-masing kebutuhan adalah dengan menggunakan kuesioner. Responden dari kuesioner adalah populasi pengguna stasiun kerja, yaitu kelima pekerja di home industry Desa Kedung Dalem. Tingkat kepentingan setiap atribut kebutuhan konsumen untuk meja dan kursi kerja dapat dilihat pada Tabel 2. Pada tabel 2, dapat dilihat bahwa tingkat kepentingan tertinggi ada pada atribut kebutuhan meja yang mendukung 
posisi duduk dengan kaki diluruskan, kursi yang mendukung posisi duduk dengan kaki yang diluruskan serta meja memiliki ukuran yang tidak terlalu besar. Tingkat kebutuhan konsumen untuk alat bantu dapat dilihat pada Tabel 3. Dari tabel 3, dapat dilihat bahwa atribut kebutuhan alat bantu dengan tingkat kepentingan tertinggi adalah: alat bantu mudah untuk digunakan serta hasil pelubangan rapi dan akurat. Atribut kebutuhan alat bantu memiliki estetika yang bagus mempunyai tingkat kepentingan terendah.

Tabel 2. Tingkat kepentingan kebutuhan konsumen untuk meja dan kursi kerja

\begin{tabular}{|l|c|}
\hline \multicolumn{1}{|c|}{ Kebutuhan } & $\begin{array}{c}\text { Rata-rata Tingkat } \\
\text { Kepentingan }\end{array}$ \\
\hline Meja memiliki ukuran yang tidak terlalu besar & 4,4 \\
\hline Meja yang mudah untuk dipindahkan & 3,4 \\
\hline Meja yang kuat & 3,4 \\
\hline Meja memiliki tempat untuk meletakkan material & 3,0 \\
\hline Meja yang mendukung posisi duduk dengan kaki yang diluruskan & 4,8 \\
\hline Kursi yang mudah untuk dipindahkan & 1,2 \\
\hline Kursi yang kuat & 3,4 \\
\hline Alas dudukan kursi yang nyaman untuk diduduki & 4,4 \\
\hline Kursi yang mendukung posisi duduk dengan kaki yang diluruskan & 4,8 \\
\hline
\end{tabular}

Tabel 3. Tingkat kepentingan kebutuhan konsumen untuk alat bantu

\begin{tabular}{|c|l|c|}
\hline No. & Atribut Kebutuhan & $\begin{array}{l}\text { Rata-Rata Tingkat } \\
\text { Kepentingan }\end{array}$ \\
\hline 1 & Alat bantu mudah untuk digunakan & 4.6 \\
\hline 2 & Alat bantu menggunakan tenaga yang ringan & 4.4 \\
\hline 3 & Alat bantu ringan & 3.4 \\
\hline 4 & Alat bantu dapat menggunakan bermacam mata pehubang & 4.4 \\
\hline 5 & Alat bantu memiliki dua fungsi untuk mehubang dan mengepress & 4.4 \\
\hline 6 & Hasil pehubangan rapih dan akurat & 4.6 \\
\hline 7 & Alat bantu memiliki estetika yang bagus & 2.2 \\
\hline
\end{tabular}

Selanjutnya ditentukan respon teknis untuk setiap kebutuhan dan tingkat hubungan antara kebutuhan dengan respon teknis serta arah pengembangannya. Hubungan antara kebutuhan pelanggan dan respon teknis untuk alat bantu dapat dilihat pada Tabel 4, sedangkan hubungan kebutuhan pelanggan dan respon teknis untuk meja dan kursi dapat dilihat pada Tabel 5. Berdasarkan tabel 4, dapat dilihat bahwa tingkat hubungan antara setiap atribut kebutuhan pelanggan dengan respon teknis untuk meja dan kursi adalah kuat. Pada tabel 5, dapat dilihat bahwa tingkat hubungan antara kebutuhan pelanggan dengan respon teknis untuk alat bantu bervariasi dari lemah hingga kuat. Tingkat hubungan yang kuat terdapat pada hubungan antara:

- alat bantu mudah untuk digunakan dengan waktu pengoperasian dan ukuran pegangan handle.

- alat bantu menggunakan tenaga yang ringan dengan panjang handle

- alat bantu ringan dengan material yang ringan dan ukuran alat bantu

- alat bantu dapat menggunakan bermacam mata pelubang/pengepres dengan rentang ukuran mata pelubang/pengepres yang dapat digunakan

- alat bantu memiliki dua fungsi yaitu melubangi dan mengepres dengan rentang ukuran mata pelubang/pengepres yang dapat digunakan

- hasil pelubangan dan pengepresan yang rapi dan akurat dengan alat bantu yang rigid

- alat bantu memiliki estetika yang bagus dengan desain alat bantu. 
Tabel 4. Hubungan antara kebutuhan pelanggan dan respon teknis untuk meja dan kursi

\begin{tabular}{|l|l|l|}
\hline \multicolumn{1}{|c|}{ Kebutuhan } & \multicolumn{1}{c|}{ Respon Teknis } & \multicolumn{1}{c|}{$\begin{array}{c}\text { Tingkat } \\
\text { Hubungan }\end{array}$} \\
\hline $\begin{array}{l}\text { Meja memiliki ukuran yang tidak terlalu } \\
\text { besar }\end{array}$ & $\begin{array}{l}\text { Dimensi } \\
\text { permukaan meja }\end{array}$ & Kuat \\
\hline \multirow{2}{*}{ Meja yang mudah untuk dipindahkan } & $\begin{array}{l}\text { Material yang } \\
\text { ringan }\end{array}$ & Kuat \\
\cline { 2 - 4 } & $\begin{array}{l}\text { Gaya gesek statis } \\
\text { maksimum }\end{array}$ & Kuat \\
\hline Kursi yang mudah untuk dipindahkan & $\begin{array}{l}\text { Material yang } \\
\text { ringan }\end{array}$ & Kuat \\
\hline $\begin{array}{l}\text { Meja memiliki tempat untuk meletakkan } \\
\text { material }\end{array}$ & $\begin{array}{l}\text { Jumlah tempat } \\
\text { penyimpanan }\end{array}$ & Kuat \\
\hline \multirow{2}{*}{$\begin{array}{l}\text { Alas dudukan kursi yang nyaman untuk } \\
\text { diduduki }\end{array}$} & $\begin{array}{l}\text { Tingkat kekerasan } \\
\text { bantalan }\end{array}$ & Kuat \\
\cline { 2 - 4 } & $\begin{array}{l}\text { Dimensi dudukan } \\
\text { kursi }\end{array}$ & Kuat \\
\hline $\begin{array}{l}\text { Meja yang mendukung posisi duduk dengan } \\
\text { kaki yang diluruskan }\end{array}$ & Tinggi kaki meja & Kuat \\
\hline $\begin{array}{l}\text { Kursi yang mendukung posisi duduk dengan } \\
\text { kaki yang diluruskan }\end{array}$ & Tinggi kursi & Kuat \\
\hline Meja yang kuat & Material yang rigid & Kuat \\
\hline Kursi yang kuat & Material yang rigid & Kuat \\
\hline
\end{tabular}

Tabel 5. Hubungan antara kebutuhan pelanggan dan respon teknis untuk alat bantu

\begin{tabular}{|c|c|c|}
\hline Kebutuhan & Respon Teknis & Tingkat Hubungan \\
\hline \multirow{5}{*}{ Alat bantu mudah untuk digunakan } & Waktu pengoperasian & Kuat \\
\hline & Panjang handle & Sedang \\
\hline & Ukuran pegangan handle & Kuat \\
\hline & Rigid & Sedang \\
\hline & Ukuran alat bantu & Sedang \\
\hline \multirow{3}{*}{$\begin{array}{l}\text { Alat bantu menggunakan tenaga yang } \\
\text { ringan }\end{array}$} & Kekuatan per & Sedang \\
\hline & Panjang handle & Kuat \\
\hline & Ukuran pegangan handle & Lemah \\
\hline \multirow{2}{*}{ Alat bantu ringan } & Material yang ringan & Kuat \\
\hline & Ukuran alat bantu & Kuat \\
\hline \multirow{2}{*}{$\begin{array}{l}\text { Alat bantu dapat menggunakan } \\
\text { bermacam mata pelubang }\end{array}$} & $\begin{array}{l}\text { Rentang ukuran mata yang } \\
\text { dapat digunakan }\end{array}$ & Kuat \\
\hline & $\begin{array}{l}\text { Ketinggian posisi mata } \\
\text { pelubang }\end{array}$ & Sedang \\
\hline \multirow{2}{*}{$\begin{array}{l}\text { Alat bantu memiliki dua fungsi untuk } \\
\text { melubang dan mengepress }\end{array}$} & $\begin{array}{l}\text { Rentang ukuran mata yang } \\
\text { dapat digunakan }\end{array}$ & Kuat \\
\hline & $\begin{array}{l}\text { Ketinggian posisi mata } \\
\text { pelubang }\end{array}$ & Sedang \\
\hline \multirow{3}{*}{$\begin{array}{l}\text { Hasil pelubangan dan pengepressan } \\
\text { rapih dan akurat }\end{array}$} & Rigid & Kuat \\
\hline & $\begin{array}{l}\text { Jarak pandang ke mata } \\
\text { pelubang }\end{array}$ & Sedang \\
\hline & $\begin{array}{l}\text { Ketinggian posisi mata } \\
\text { pelubang }\end{array}$ & Sedang \\
\hline \multirow{2}{*}{ Alat bantu memiliki estetika yang bagus } & Ukuran alat bantu & Sedang \\
\hline & Desain alat bantu & Kuat \\
\hline
\end{tabular}


Setelah itu ditentukan nilai target dari setiap respon teknis. Nilai respon teknis untuk meja dan kursi dapat dilihat pada tabel 6.

Tabel 6. Nilai target untuk setiap respon teknis meja dan kursi

\begin{tabular}{|l|l|l|l|}
\hline Respon Teknis & Kriteria & Nilai Target & Unit \\
\hline $\begin{array}{l}\text { Dimensi permukaan } \\
\text { meja }\end{array}$ & $\begin{array}{l}\text { Panjang dan lebar permukaan } \\
\text { meja yang optimal }\end{array}$ & $\begin{array}{l}\text { Panjang: } 80 \\
\text { Lebar: } 50\end{array}$ & $\mathrm{~cm}$ \\
\hline $\begin{array}{l}\text { Gaya gesek statis } \\
\text { maksimum }\end{array}$ & $\begin{array}{l}\text { Gobot per satuan panjang / } \\
\text { selume }\end{array}$ & $\begin{array}{l}\text { Rangka meja / kursi: } \\
\text { sebelum benda bergerak } \\
\text { Daun meja: }<1\end{array}$ & $<95 / \mathrm{m}$ \\
\hline $\begin{array}{l}\text { Jumlah tempat } \\
\text { penyimpanan }\end{array}$ & Jumlah material & $\mathrm{gr} / \mathrm{cm}^{3}$ \\
\hline $\begin{array}{l}\text { Tingkat kekerasan } \\
\text { bantalan }\end{array}$ & Density busa & $\mathrm{N}$ \\
\hline $\begin{array}{l}\text { Dimensi dudukan } \\
\text { kursi }\end{array}$ & $\begin{array}{l}\text { data antropometri lebar } \\
\text { pinggul dan jarak bokong ke } \\
\text { popliteal }\end{array}$ & $\begin{array}{l}\text { lebar: } 45 \\
\text { kedalaman: } 40\end{array}$ & $\mathrm{Unit}$ \\
\hline Tinggi kaki meja & data antropometri tinggi lutut & 57 & $\mathrm{Kg} / \mathrm{m}^{3}$ \\
\hline Tinggi kursi & $\begin{array}{l}\text { data antropometri tinggi } \\
\text { popliteal }\end{array}$ & 40 & $\mathrm{~cm}$ \\
\hline Material yang rigid & Tensile strength & $\begin{array}{l}\text { Rangka meja dan kursi: }>400 \\
\text { Daun meja: }>30\end{array}$ & $\mathrm{~cm}$ \\
\hline
\end{tabular}

Untuk meja dan kursi, dimensi yang digunakan mengacu pada data antropometri pekerja seperti terlihat pada tabel 7 .

Tabel 7. Data Antropometri

\begin{tabular}{|l|l|r|r|r|r|r|r|r|}
\cline { 3 - 6 } \multicolumn{2}{c|}{} & \multicolumn{4}{|c|}{ pekerja } & rata- & standar \\
rata & deviasi \\
\hline dimensi benda & dimensi tubuh $(\mathrm{mm})$ & 1 & 2 & 3 & 4 & 5 & 409 & 7.42 \\
\hline kedalaman kursi & panjang popliteal & 420 & 410 & 405 & 400 & 410 & 409 & 43.42 \\
\hline tinggi kaki meja & tinggi lutut & 480 & 450 & 450 & 470 & 470 & 464 & 130 \\
\hline lebar kursi & lebar pinggul & 420 & 390 & 380 & 370 & 370 & 386 & 20.74 \\
\hline tinggi kursi & tinggi popliteal & 420 & 420 & 410 & 420 & 415 & 417 & 4.47 \\
\hline
\end{tabular}

Untuk kedalaman kursi digunakan data 50\%ile panjang popliteal sehingga didapatkan ukuran $40 \mathrm{~cm}$. Untuk tinggi kaki meja digunakan data 95\%ile tinggi lutut dengan perhitungan sebagai berikut: $\mathrm{x}_{95 \% \text { ile }}=464+1,64 \mathrm{x} 13,42=486 \mathrm{~mm}=49 \mathrm{~cm}$ ditambah toleransi $8 \mathrm{~cm}$ sehingga menjadi $57 \mathrm{~cm}$. Lebar kursi menggunakan data 95\%ile lebar pinggul $=386+1,64 \times 20,74=420$ $\mathrm{mm}=42 \mathrm{~cm}$ ditambah toleransi $3 \mathrm{~cm}$ menjadi $45 \mathrm{~cm}$. untuk tinggi kursi digunakan data $5 \%$ ile tinggi popliteal $=417-1,64 \times 4,47=410 \mathrm{~mm}$ dibulatkan menjadi $40 \mathrm{~cm}$. 
Nilai target untuk respon teknis alat bantu dapat dilihat pada tabel 8 .

Tabel 8. Nilai target untuk respon teknis alat bantu

\begin{tabular}{|c|c|c|c|c|}
\hline No & Respon Teknis & Kriteria & Nilai Target & Unit \\
\hline \multirow[t]{2}{*}{1} & \multirow[t]{2}{*}{ Waktu pengoperasian } & $\begin{array}{l}\text { Waktu untuk melakukan } 5 \\
\text { kali pelubangan }\end{array}$ & $<15$ & detik \\
\hline & & Waktu persiapan & $<60$ & detik \\
\hline 2 & Ukuran pegangan handle & Diameter pegangan & 43 & $\mathrm{~mm}$ \\
\hline 3 & Panjang handle & $\begin{array}{l}\text { Panjang handle dari titik } \\
\text { putar }\end{array}$ & 50 & $\mathrm{~cm}$ \\
\hline 4 & Rigid & Shear Modulus & $>80$ & $\mathrm{GPa}$ \\
\hline \multirow{3}{*}{5} & \multirow{3}{*}{ Ukuran alat bantu } & Lebar alat bantu & 30 & $\mathrm{~cm}$ \\
\hline & & Panjang alat bantu & 30 & $\mathrm{~cm}$ \\
\hline & & Tinggi alat bantu & 40 & $\mathrm{~cm}$ \\
\hline 6 & Kekuatan per & Kekuatan per & 100 & $\mathrm{~N}$ \\
\hline 7 & Material yang ringan & Massa jenis & $<10$ & $\mathrm{~g} / \mathrm{cm} 3$ \\
\hline 8 & Rentang ukuran mata yang dapat digunakan & $\begin{array}{l}\text { Rentang diameter mata } \\
\text { pelubang yang dapat dipakai }\end{array}$ & $3-13$ & $\mathrm{~mm}$ \\
\hline 9 & Ketinggian posisi mata pelubang & $\begin{array}{l}\text { Jarak mata peubang ke } \\
\text { permukaan kulit sintetis }\end{array}$ & $<1$ & $\mathrm{~cm}$ \\
\hline 10 & Jarak pandang ke mata pelubang & $\begin{array}{l}\text { Jarak pandang ke mata } \\
\text { pelubang }\end{array}$ & $<30$ & $\mathrm{~cm}$ \\
\hline 11 & Desain alat bantu & $\begin{array}{l}\text { Skala Keindahan dari alat } \\
\text { bantu }\end{array}$ & 3 & Skala \\
\hline
\end{tabular}

Nilai target untuk waktu pengoperasian, dibagi menjadi 2 kriteria, yaitu waktu untuk melakukan 5 kali pelubangan dan waktu persiapan. Untuk waktu pelubangan ditentukan target kurang dari 15 detik dikarenakan waktu pelubangan saat ini adalah 15 detik untuk 5 lubang. Untuk waktu persiapan telah ditentukan kurang dari 60 detik, karena menurut Polgar (1996) waktu yang dibutuhkan untuk mengganti mata pelubang adalah 30 detik. Namun untuk alat bantu ini perlu dilakukan penggantian alas juga, oleh sebab itu target adalah kurang dari 60 detik. Untuk ukuran pegangan handle, kriteria yang digunakan adalah diameter pegangan. Dikarenakan lebar pintu di industri rumahan sebesar $76 \mathrm{~cm}$, maka ukuran handle tidak boleh terlalu panjang serta ukuran alat bantu juga tidak boleh terlalu besar. Kriteria rigid ditentukan dari shear modulus material yang digunakan, karena shear modulus merupakan salah satu konstanta elastis yang berhubungan dengan kekuatan suatu material (Bhavikatti, 2015). Rentang ukuran mata pelubang ditentukan dari mata pelubang yang sudah ada. yaitu dengan rentang diameter dari 3-13 mm. Untuk ketinggian posisi mata pelubang diperlukan jarak sekecil mungkin untuk meningkatkan akurasi. Ringkasan dari hubungan antara atribut kebutuhan konsumen dan respon teknis dapat dilihat pada HOQ (gambar 4-6). 


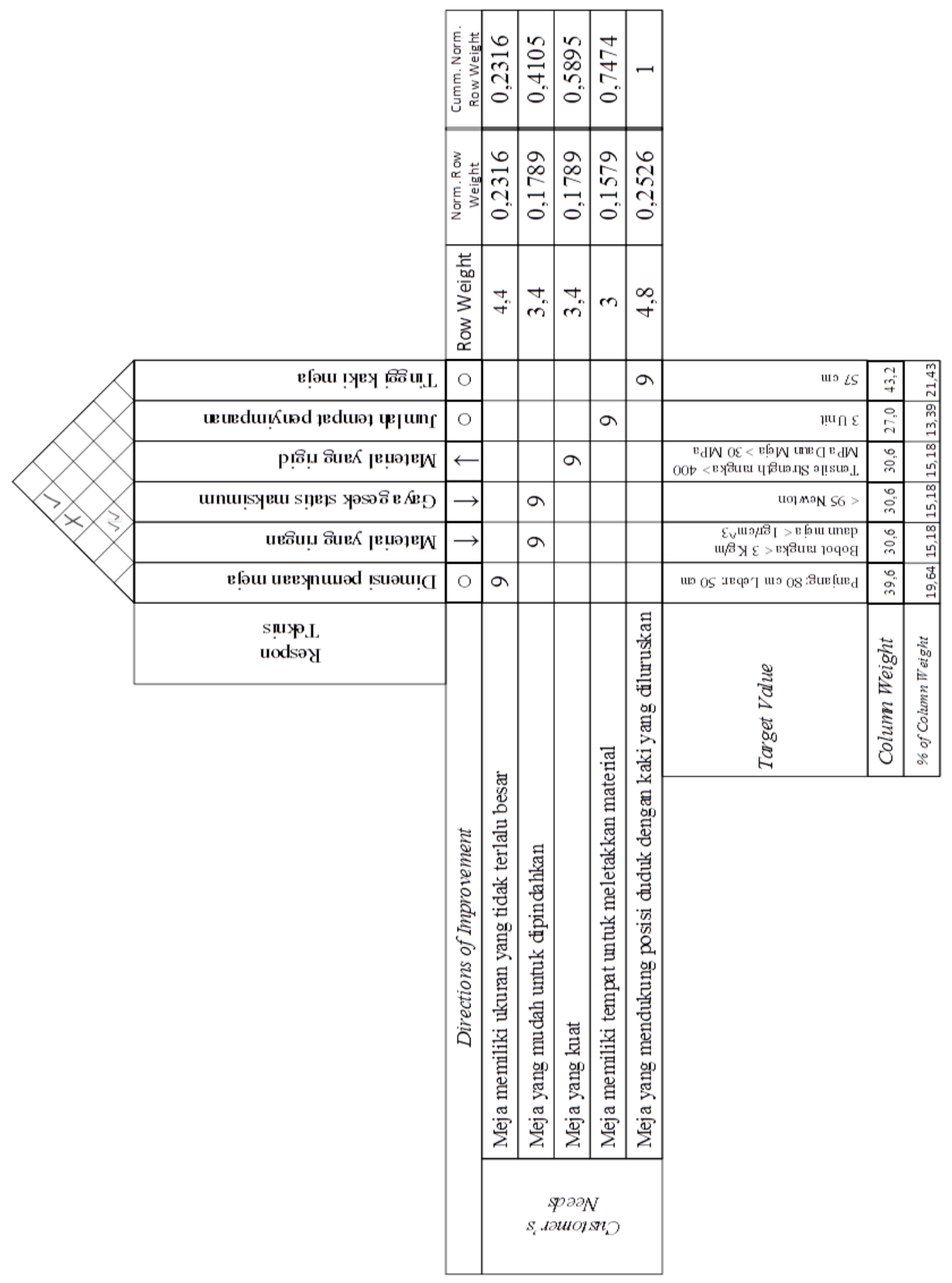

Gambar 4. House of Quality meja kerja 


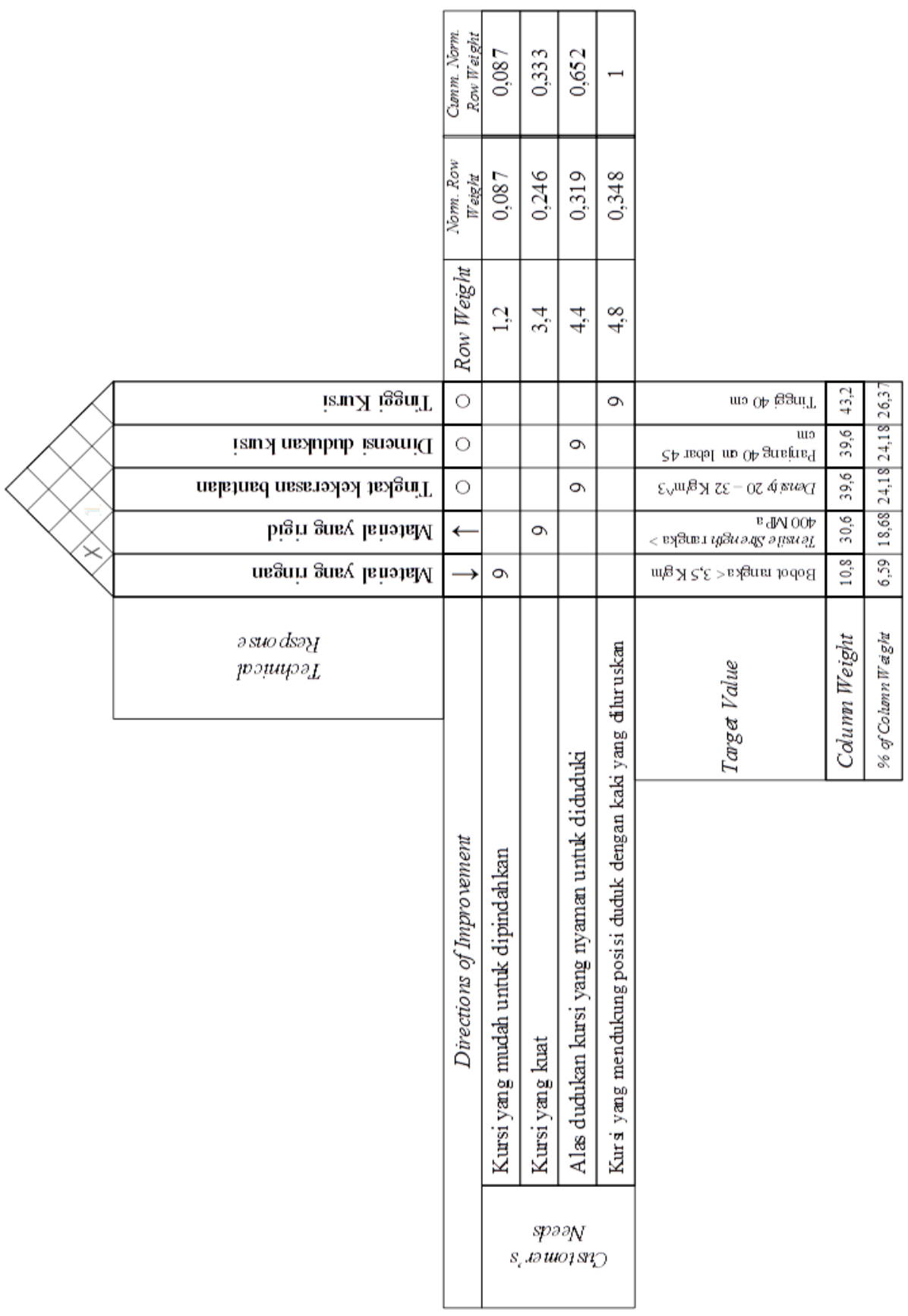

Gambar 5. House of Quality kursi kerja 


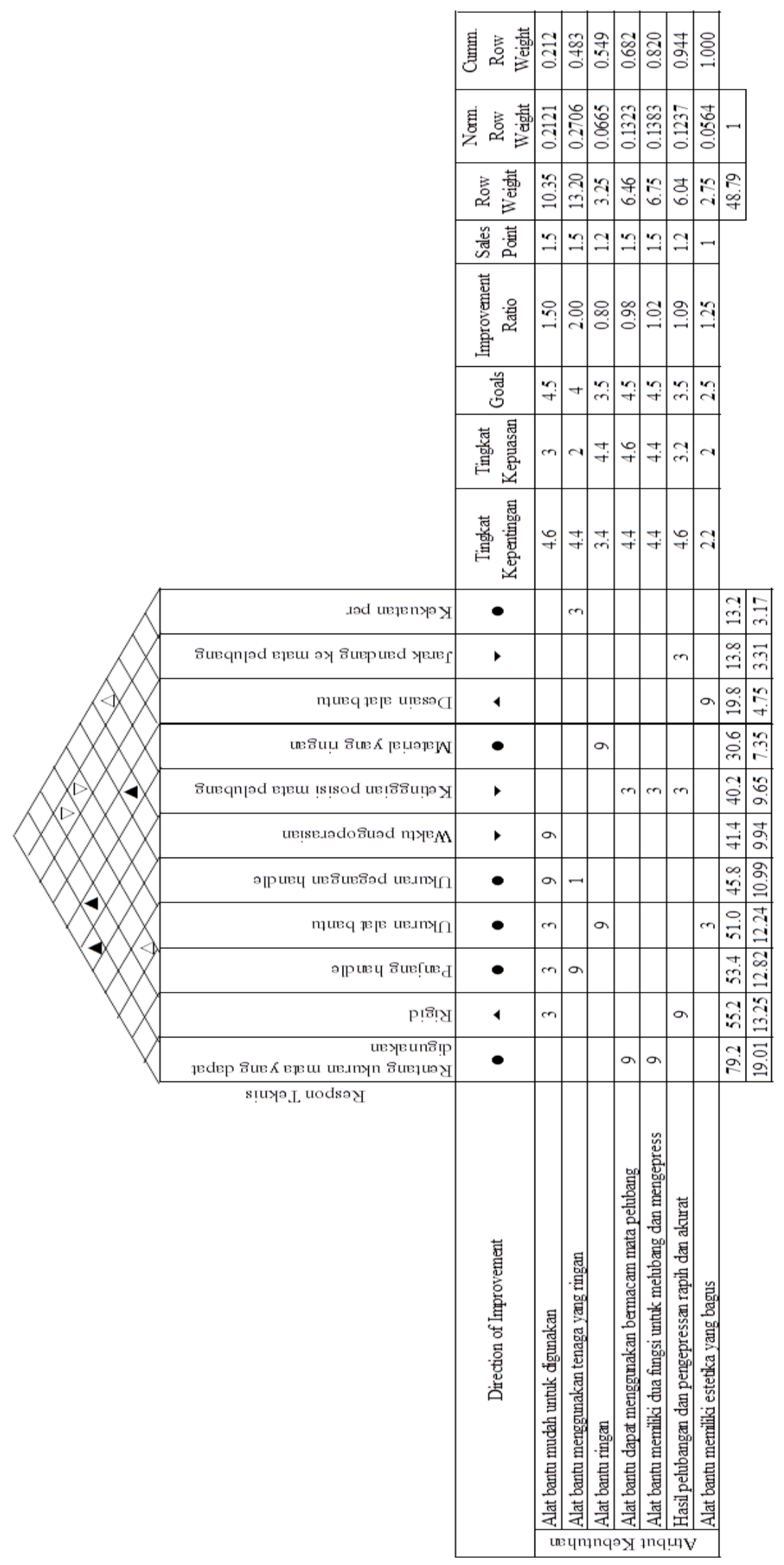

Gambar 6. House of Quality alat bantu 
Berdasarkan house of quality pada gambar 6, tiga atribut kebutuhan yang memiliki row weight terbesar adalah:

- Alat bantu menggunakan tenaga yang ringan

- Alat bantu mudah digunakan

- Alat bantu memiliki dua fungsi untuk melubangi dan mengepress sedangkan lima respon teknis dengan column weight terbesar adalah:

- Ukuran mata pelubang yang dapat digunakan

- $\quad$ Rigid

- Panjang handle

- Ukuran alat bantu

- Ukuran pegangan handle.

Lima respon teknis dan tiga atribut kebutuhan diatas, akan dijadikan dasar pengembangan beberapa konsep alternatif.

Pada konsep alternatif 1, alat bantu ini menggunakan bahan utama besi, metode pengerjaan menggunakan kaki, sistem penahan mata menggunakan kepala bor, pengangan handle terbuat dari besi, menggunakan sistem penyambung sekup dan menggunakan alat bantu obeng. Sebaliknya pada konsep alternatif 2 , bahan utama dari alat bantu berupa baja, dengan metode pengerjaan menggunakan tangan dalam posisi duduk, menggunakan kepala bor sebagai sistem penahan mata, bagian handle terbuat dari karet, disambung menggunakan las dan menggunakan alat bantu seperti obeng. Di konsep alternatif 3, bahan utama dari alat ini terbuat dari besi, metode pengerjaan menggunakan tangan, namun dalam posisi berdiri, sistem untuk penahan mata menggunakan silinder kosong, pengangan handle terbuat dari kain, disambung menggunakan las, dan menggunakan alat bantu berupa obeng. Gambar konsep alternatif 1, 2 dan 3 dapat dilihat pada gambar 7 .

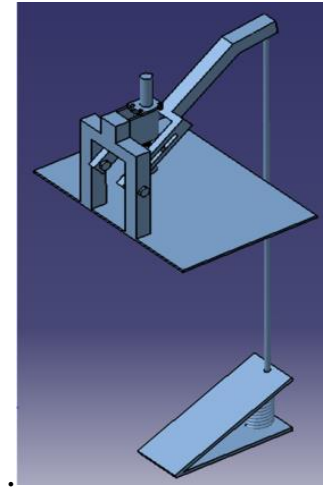

(a) konsep alternatif 1 3

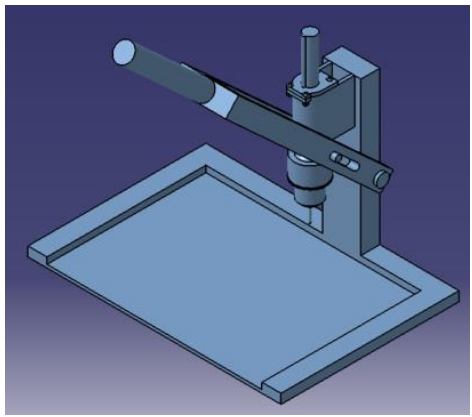

(b) konsep alternatif 2

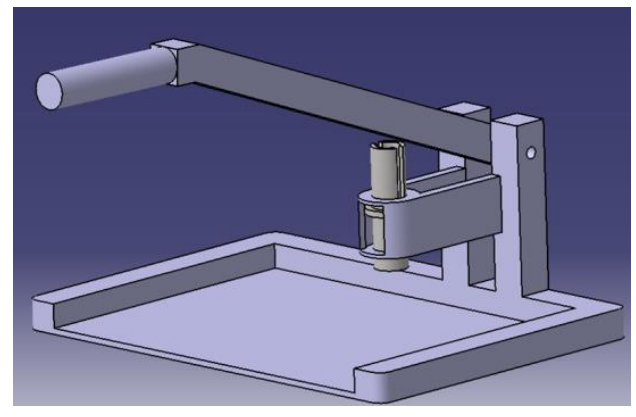

(c) konsep alternatif

Gambar 7. Konsep desain alat bantu

Dari ketiga alternatif tersebut, dilakukan penilaian berdasarkan beberapa kriteria. Hasil penilaian dapat dilihat pada tabel 9. Pada tabel 9, dapat dilihat jika alternatif terpilih adalah konsep alternatif 2.

Tabel 9. Matriks penilaian alternatif desain alat bantu

\begin{tabular}{|c|c|c|c|c|c|c|c|}
\hline \multirow{2}{*}{ Kriteria } & \multirow{2}{*}{ Bobot } & \multicolumn{2}{|c|}{ Alternatif 1} & \multicolumn{2}{|c|}{ Alternatif 2} & \multicolumn{2}{|c|}{ Alternatif 3} \\
\hline & & Rating & Nilai Bobot & Rating & Nilai Bobot & Rating & Nilai Bobot \\
\hline Fungsionalitas & $30.30 \%$ & 4.5 & 1.36 & 4.75 & 1.44 & 3.75 & 1.14 \\
\hline Kemudahan Penggunaan & $28.79 \%$ & 3.5 & 1.01 & 4 & 1.15 & 4 & 1.15 \\
\hline Proses Pembuatan & $15.15 \%$ & 3 & 0.45 & 4.25 & 0.64 & 3.5 & 0.53 \\
\hline Harga & $18.18 \%$ & 3.25 & 0.59 & 3.25 & 0.59 & 2.75 & 0.50 \\
\hline Estetika & $7.58 \%$ & 1.75 & 0.13 & 3 & 0.23 & 2.75 & 0.21 \\
\hline & & Total & 3.55 & Total & 4.05 & Total & 3.53 \\
\hline
\end{tabular}


Demikian pula,dikembangkan konsep alternatif desain meja dan kursi berdasarkan HOQ yang sudah dibuat. Alternatif desain meja 1 terdiri dari 1 meja utama dengan 2 meja tambahan. Meja utama pada bagian tengah dibuat dengan ukuran yang tidak terlalu besar dengan alasan tidak memakan tempat, namun tetap dapat memberikan keleluasaan bagi penggunanya. Kegunaan dari meja utama adalah untuk menaruh alat pelubangan dan pengepresan. Mekanisme perluasan area kerja ini dilakukan dengan cara mengangkat dan mengaitkan meja tambahan pada komponen penyangga yang berada di bagian kiri dan kanan meja utama. Fungsi dari meja tambahan ini adalah untuk menaruh material kulit sebelum diproses pada satu sisi dan setelah selesai diproses pada sisi lainnya. Alternatif desain meja 2 memiliki rancangan yang berbeda hanya dalam hal mekanisme perluasan bidang kerja. Perluasan dilakukan dengan cara menarik keluar dua komponen meja tambahan yang terpasang pada rel di bawah laci penyimpanan. Mekanisme penarikan dilakukan ke arah luar sisi kiri dan kanan meja utama. Meja pada alternatif ketiga memiliki perbedaan yang cukup signifikan dibandingkan kedua alternatif lainnya. Meja ini hanya memiliki satu komponen meja tambahan pada sisi kiri dari meja utama. Meja utama dibuat lebih besar guna memberikan ruang untuk menempatkan 3 slot penyimpanan di sisi kanan bawah permukaan meja utama. Ketiga alternatif konsep desain meja dapat dilihat pada gambar 8 .

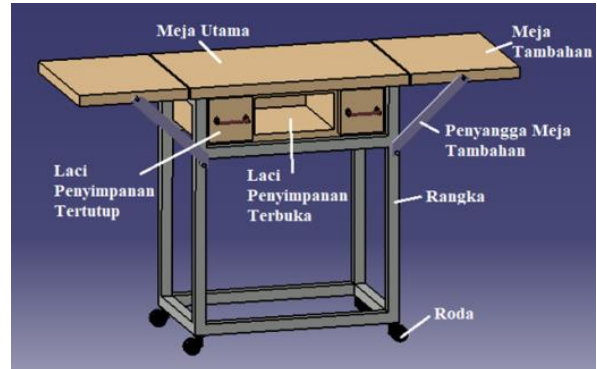

(a) alternatif meja 1

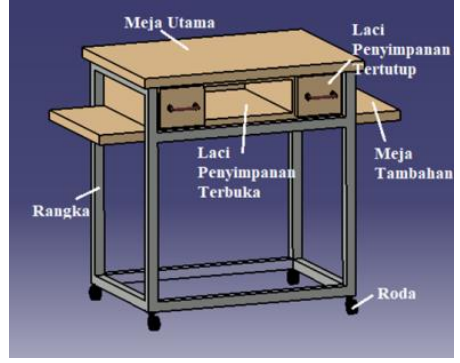

(b) alternatif meja 2

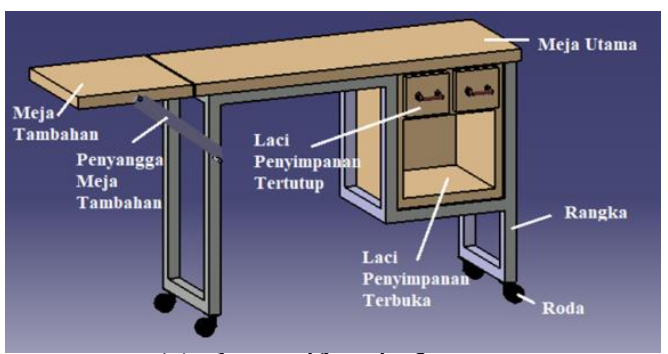

(c) alternatif meja 3

Gambar 8. Konsep desain alternatif meja kerja

Alternatif desain kursi 1 menggunakan rangka kursi dengan besi hollow berbentuk segi empat. Dudukan kursi menggunakan bantalan busa yang dilapisi dengan bahan kulit sintetis. Alternatif desain 2 menggunakan rangka kursi dengan besi hollow berbentuk silinder. Mengikuti bentuk dari rangkanya, permukaan bantalan duduk berbentuk melingkar dengan diameter yang dapat mengakomodasi lebar pinggul pekerja. Kedua alternatif desain kursi dapat dilihat pada gambar 9.

Kemudian dilakukan pemilihan alternatif meja dan kursi berdasarkan kriteria tertentu yang dapat dilihat pada tabel 10-11. Dari tabel 10 dapat dilihat bahwa konsep meja terpilih adalah alternatif meja 1, sedangkan pada tabel 11 dapat dilihat konsep kursi yang terpilih adalah alternatif kursi 1. 


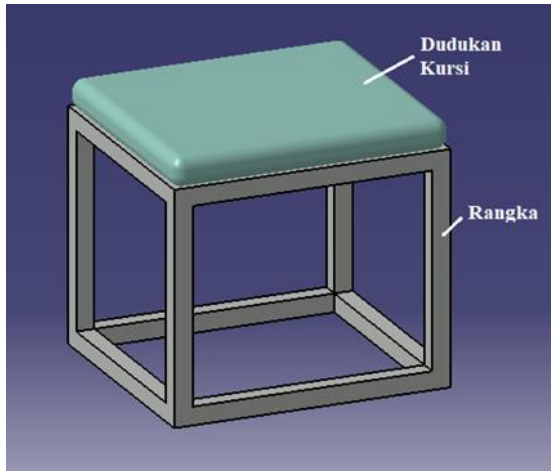

(a) alternatif kursi 1

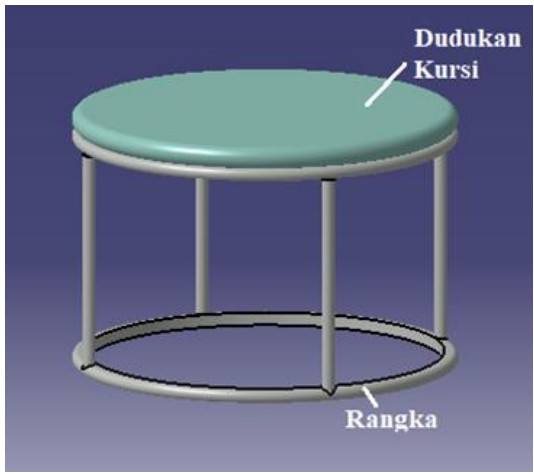

(b) alternatif kursi 2

Gambar 9. Konsep desain alternatif kursi kerja

Tabel 10. Matriks penilaian alternatif desain meja

\begin{tabular}{|c|c|c|c|c|c|c|c|}
\hline \multirow[b]{3}{*}{ Kriteria Seleksi } & \multirow{3}{*}{$\begin{array}{l}\text { Persentase } \\
\text { Bobot }(\%)\end{array}$} & \multicolumn{6}{|c|}{ Konsep } \\
\hline & & \multicolumn{2}{|c|}{1} & \multicolumn{2}{|c|}{2} & \multicolumn{2}{|c|}{3} \\
\hline & & $\begin{array}{c}\text { Nilai } \\
\text { Rata- } \\
\text { rata }\end{array}$ & $\begin{array}{l}\text { Nilai } \\
\text { Bobot }\end{array}$ & $\begin{array}{c}\text { Nilai } \\
\text { Rata- } \\
\text { rata }\end{array}$ & $\begin{array}{l}\text { Nilai } \\
\text { Bobot }\end{array}$ & $\begin{array}{c}\text { Nilai } \\
\text { Rata- } \\
\text { rata }\end{array}$ & $\begin{array}{c}\text { Nilai } \\
\text { Bobot }\end{array}$ \\
\hline Harga & 21 & 3,75 & 0,79 & 4 & 0,84 & 4,25 & 0,89 \\
\hline Fungsionalitas & 24 & 4,75 & 1,14 & 4,5 & 1,08 & 3 & 0,72 \\
\hline Estetika & 13 & 4,5 & 0,59 & 4 & 0,52 & 2,5 & 0,33 \\
\hline Kenyamanan & 24 & 4,5 & 1,08 & 4,25 & 1,02 & 4 & 0,96 \\
\hline $\begin{array}{c}\text { Kemudahan } \\
\text { Pembuatan } \\
\end{array}$ & 18 & 3,5 & 0,63 & 2,75 & 0,50 & 3,75 & 0,68 \\
\hline Total & 100 & - & 4,22 & - & 3,96 & - & 3,57 \\
\hline
\end{tabular}

Tabel 11. Matriks penilaian alternatif desain kursi

\begin{tabular}{|c|c|c|c|c|c|}
\hline \multirow{3}{*}{ Kriteria Seleksi } & \multirow{3}{*}{$\begin{array}{c}\text { Persentase Bobot } \\
(\%)\end{array}$} & \multicolumn{4}{|c|}{ Konsep } \\
\hline & & \multicolumn{2}{|c|}{1} & \multicolumn{2}{|c|}{2} \\
\hline & & $\begin{array}{c}\text { Nilai Rata- } \\
\text { rata }\end{array}$ & $\begin{array}{l}\text { Nilai } \\
\text { Bobot }\end{array}$ & $\begin{array}{l}\text { Nilai Rata- } \\
\text { rata }\end{array}$ & $\begin{array}{l}\text { Nilai } \\
\text { Bobot }\end{array}$ \\
\hline Harga & 21 & 4 & 0,84 & 3,25 & 0,68 \\
\hline Fungsionalitas & 24 & 5 & 1,20 & 5 & 1,20 \\
\hline Estetika & 13 & 4 & 0,52 & 4,75 & 0,62 \\
\hline Kenyamanan & 24 & 5 & 1,20 & 4 & 0,96 \\
\hline $\begin{array}{l}\text { Kemudahan } \\
\text { Pembuatan }\end{array}$ & 18 & 5 & 0,90 & 3,25 & 0,59 \\
\hline Total & 100 & - & 4,66 & - & 4,05 \\
\hline
\end{tabular}

Setelah konsep desain dipilih, maka tahap selanjutnya adalah pembuatan alat bantu, meja dan kursi kerja. Meja kerja berikut kursi dan alat bantu yang sudah dibuat dapat dilihat pada gambar 10. Pada tahap selanjutnya dilakukan perbandingan waktu persiapan, waktu pengoperasian dan waktu pembersihan antara metode lama dan metode baru. Dari hal ini waktu persiapan berupa waktu persiapan yang perlu dilakukan sebelum dapat melakukan proses pelubangan. Waktu pengoperasian berupa waktu yang diperlukan untuk melakukan pelubangan sebanyak 5 kali. Hal ini dikarenakan jika hanya dilakukan 1 kali waktu tercatat akan menjadi terlalu cepat. Waktu pembersihan berupa waktu yang diperlukan untuk membersihkan mata pelubang dari sisa kulit sintetis. 


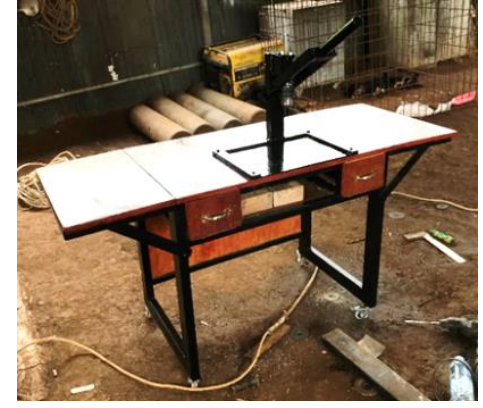

(a) meja kerja dan alat bantu

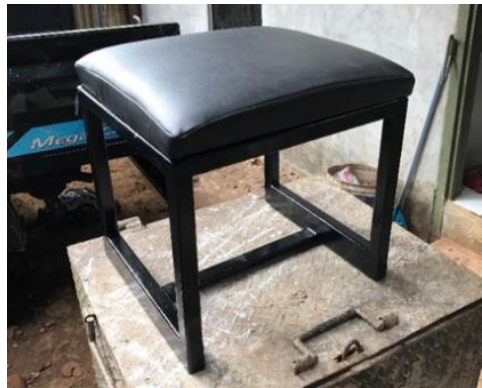

(b) kursi kerja

Gambar 10. Stasiun kerja dan alat bantu yang sudah selesai dibuat

Untuk metode lama (dapat dilihat di gambar 11), pengambilan data waktu mencakup: waktu persiapan berupa waktu untuk memilih dan mengambil mata pelubang, meletakkan kulit di atas alas, dan mengambil palu.. Waktu pengoperasian berupa waktu untuk melakukan 5 kali pelubangan pada material secara berderet. Waktu pembersihan berupa waktu untuk membersihkan mata pelubang dari sisa material menggunakan mata obeng. Semua data waktu ini diambil sebanyak 30 kali. Setelah dilakukan validasi data berupa uji kenormalan, keseragaman dan kecukupan data, maka data diolah dan didapatkan waktu persiapan rata-rata $=8,41$ detik; waktu operasi rata-rata $=19,81$ detik (untuk 5 lubang); waktu pembersihan rata-rata $=8,74$ detik.

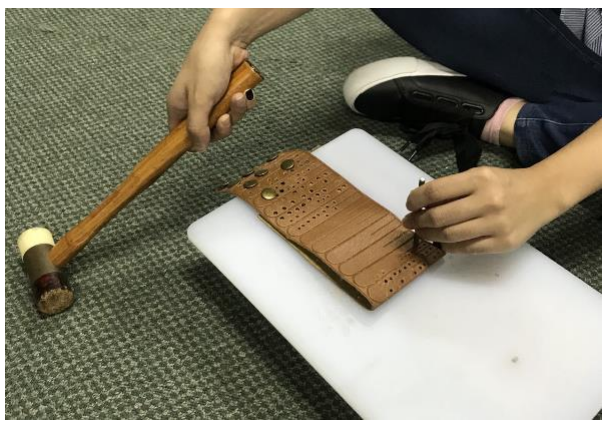

Gambar 11. Metode lama

Untuk metode baru, waktu persiapan berupa pengambilan alas dan balok kayu dari laci dan meletakkannya pada alat, kemudian mengambil mata pelubang dari laci dan memasangkan pada kepala bor dan meletakkan material di posisi yang tepat. Pada metode baru perlu dilakukan beberapa hal untuk persiapan, namun hanya perlu dilakukan sekali saja. Pemasangan mata pelubang dapat dilihat pada gambar 12 .

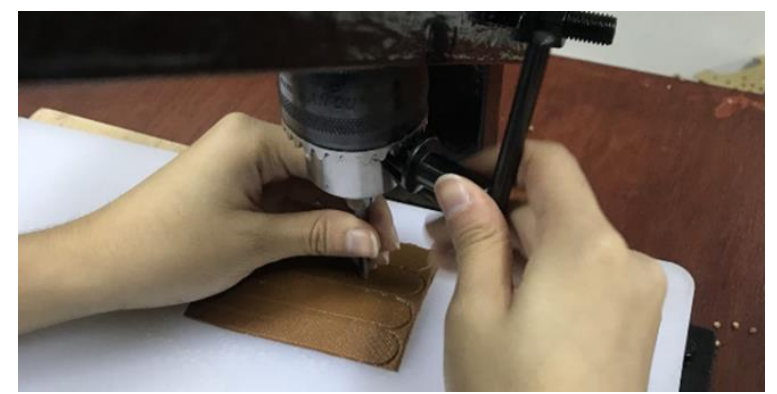

Gambar 12. Pemasangan mata pelubang pada kepala bor

Waktu pengoperasian berupa melakukan pelubangan sebanyak 5 kali secara berderet. Waktu pembersihan berupa membersihkan mata pelubang dari sisa material, namun kayu balok dan alas perlu digeser telebih dahulu untuk dibersihkan. Data masing-masing waktu diambil sebanyak 30 kali, kemudian divalidasi. Dari hasil perhitungan didapatkan bahwa waktu persiapan rata-rata $=88,03$ detik; waktu operasi rata-rata $=12,25$ detik; waktu pembersihan rata-rata $=9,97$ detik.

Dari hasil wawancara dengan para pekerja, diketahui bahwa dalam sehari industri rumahan ini dapat menyelesaikan 500 pasang bagian atas sandal wanita. Perhitungan waktu total 
untuk proses pelubangan menggunakan asumsi: rata-rata setiap pasang dilakukan 10 kali pelubangan: 5 lubang untuk bagian kiri dan 5 lubang untuk bagian kanan, dan setelah proses melubangi $30 \mathrm{kali}$, mata pelubang perlu dibersihkan. Berdasarkan asumsi tersebut, maka proses pelubangan untuk 500 pasang bagian atas sandal wanita dengan metode lama dan metode baru membutuhkan waktu sebagai berikut :

Waktu total metode lama $=$ waktu persiapan + waktu pelubangan + waktu pembersihan $=\left(8,41+1.000 \times 19,81+\frac{5000}{30} \times 8,74\right)$ detik $=21.275,08$ detik

Waktu total metode baru= waktu persiapan + waktu pelubangan + waktu pembersihan $=$ $\left(88,03+1.000 \times 12,25+\frac{5000}{30} \times 9,97\right)$ detik $=13.999,70$ detik

Kemudian data waktu total tersebut diolah untuk mendapatkan tingkat produktivitas proses pelubangan, dan didapatkan hasil sebagai berikut:

Produktivitas $($ metode lama $)=\frac{3600 \text { detik }}{1 \text { jam }}: \frac{21275,08 \text { detik }}{500 \text { pasang }}=84 \mathrm{pasang} / \mathrm{jam}$

Produktivitas $($ metode baru $)=\frac{3600 \mathrm{det} i \mathrm{k}}{1 \mathrm{jam}}: \frac{13999,70 \mathrm{deti}}{500 \mathrm{pasang}}=128 \mathrm{pasang} / \mathrm{jam}$

Peningkatan produktivitas dengan menggunakan stasiun kerja dan alat bantu menjadi $=$

$$
\left(\frac{128-84}{84}\right) \times 100 \%=52,4 \% \text {. }
$$

Selanjutnya, dilakukan analisis postur kerja proses pelubangan menggunakan stasiun kerja dan alat bantu (metode baru) dengan metode RULA (dapat dilihat pada gambar 13 dan 14). Berdasarkan gambar 14, dapat dilihat skor akhir RULA pada postur kerjayang baru turun menjadi 3 dari skor RULA sebelum perbaikan yaitu 7 (gambar 3). Hal ini berarti, adanya stasiun kerja dan alat bantu dapat menurunkan risiko cedera muskuloskeletal pada pekerja, sehingga pekerja dapat bekerja lebih nyaman.

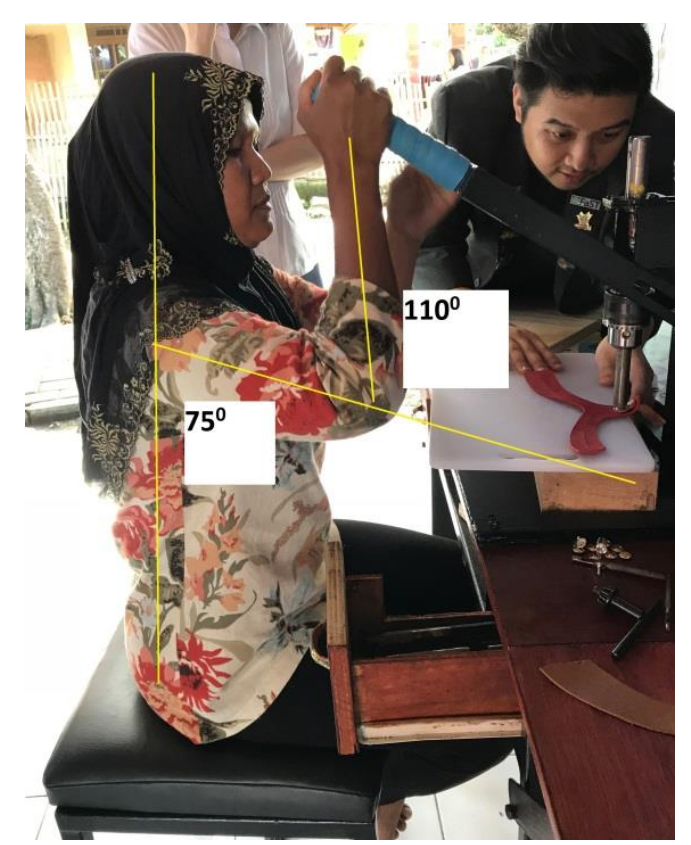

Gambar 13. Postur pekerja saat proses pelubangan dengan metode baru 
RULA Employee Assessment Worksheet

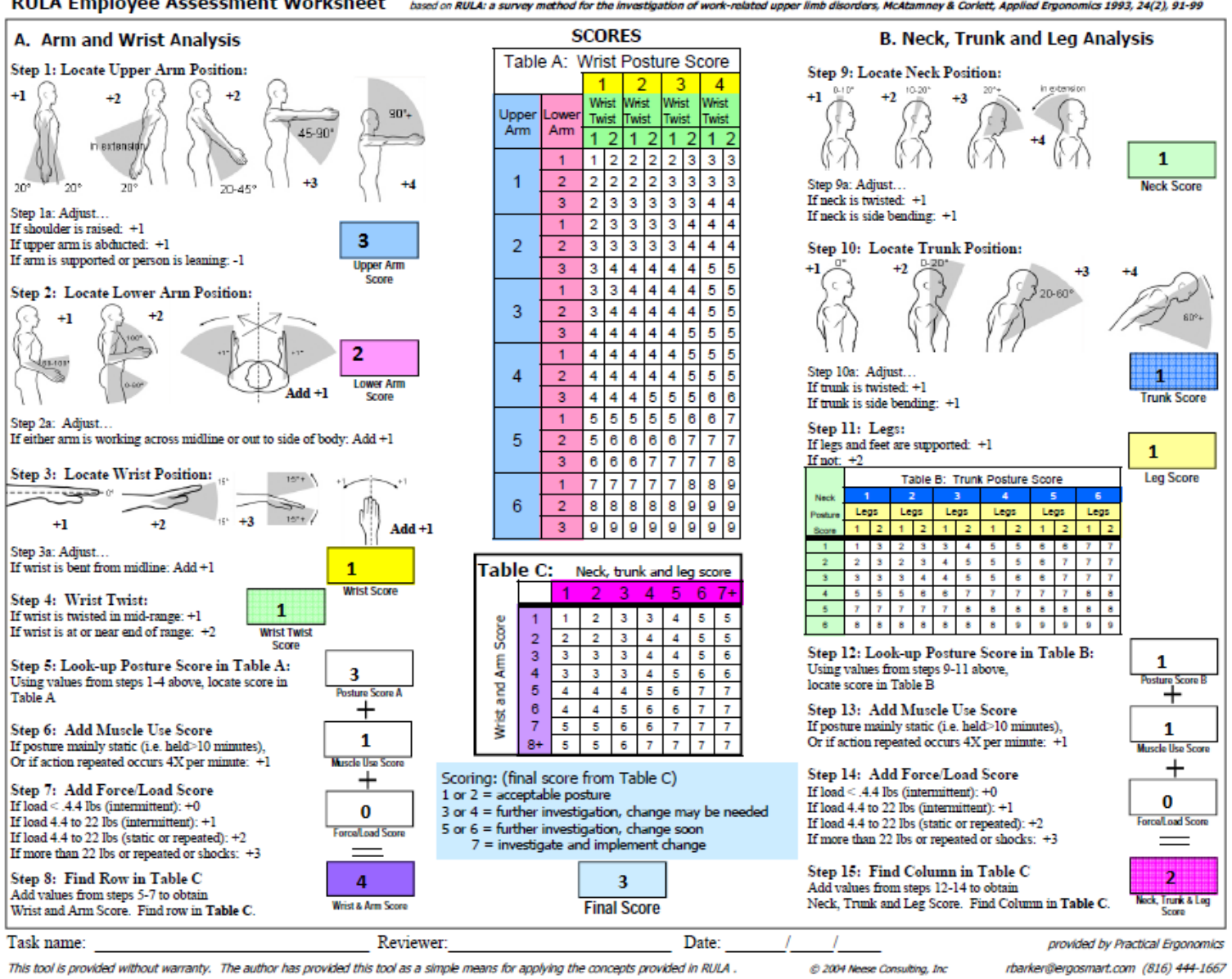

Gambar 14. Skor RULA untuk postur kerja sesudah perbaikan (metode baru).

\section{KESIMPULAN}

Kesimpulan yang dapat ditarik pada penelitian ini adalah:

1. Stasiun kerja pelubangan dan pengepresan yang telah dibuat terdiri dari meja dan kursi. Meja yang dibuat memiliki spesifikasi tinggi permukaan $75 \mathrm{~cm}$, tinggi kaki meja $57 \mathrm{~cm}$, lebar meja $50 \mathrm{~cm}$, panjang meja minimal $85 \mathrm{~cm}$ dan maksimal $110 \mathrm{~cm}$, sedangkan, kursi yang dibuat memiliki spesifikasi akhir tinggi kursi $40 \mathrm{~cm}$, lebar kursi $45 \mathrm{~cm}$ dan panjang kursi $40 \mathrm{~cm}$.

2. Alat bantu pelubangan dan pengepresan telah dibuat dengan spesifikasi akhir sebagai berikut: dimensi alat bantu: $28 \mathrm{~cm} \times 40 \mathrm{~cm} \times 50 \mathrm{~cm}$. Alat tersebut dapat mengakomodasi mata pelubang dan press dengan ukuran diameter antara $2,5 \mathrm{~mm}$ hingga $13 \mathrm{~mm}$.

3. Dengan adanya stasiun kerja dan alat bantu, produktivitas proses pelubangan meningkat dari 84 pasang/jam menjadi 128 pasang/jam atau meningkat sebesar 52,4\%.

4. Pembuatan stasiun kerja pelubangan dan pengepresan menurunkan skor RULA dari 7 (metode lama) menjadi 3 (metode baru). Hal ini mengindikasikan terjadinya penurunan risiko cedera pada pekerja. 


\section{DAFTAR PUSTAKA}

Bhavikatti,S.S. 2015. Mechanics of structures. New Delhi: Vikas Publishing House Pvt Ltd.

Cohen, Lou. 1995. Quality Function Deployment: How to Make QFD Work of You. New York: Wesley Publishing Company.

Maritan, Davide.2015. Practical Manual of Quality Function Deployment.Switzerland:Springer.

McAtamney, Lynn dan E. Nigel Corlett.1993. RULA:a survey method for the investigation of work-related upper limb disorders.Applied Ergonomics volume 24, no.2:91-99.

Polgar, K.C, T.G Gutowski, and G.W Wentworth. 1996. "Simplified Time Estimation Booklet for Basic Machining Operations."M.S. Thesis., MIT.

Ulrich, Karl T. dan Steven D. Eppinger.2012.Product Design and development. $5^{\text {th }}$ ed. New York: McGraw-Hill.

Wickens, Christopher D., John D. Lee, Yili Liu, Sallie E. Gordon Becker. 2004. An Introduction to Human Factors Engineering. $2^{\text {nd }}$ ed.New Jersey:Pearson Education, Inc. 